\title{
REVIEWS
}

\section{CHALDON HERRING: \\ Writers in a Dorset Landscape \\ Judith Stinton}

(Black Dog Books, 2004, Softback, £14.95)

Paperback reprints are usually cheaper and meaner than hardback first editions, but Black Dog Books' new reprint of Judith Stinton's Chaldon Herring (first published by the Boydell Press in 1988) is a distinct improvement on the original. The text is essentially unchanged, but there are many more illustrations and photographs, and all are enhanced by being printed on better quality paper. It is an elegant production, and a timely one, for new generations will find the book of great interest and enjoyment.

The sub-title of the original edition was 'The Powys Circle in a Dorset Village', and this has now been changed to 'Writers in a Dorset Landscape'. Both are correct, for the story of the authors, poets and artists discussed by Judith Stinton begins with Theodore Powys, and it was his presence at Chaldon Herring that drew others to this otherwise quiet village. The change of sub-title is, however, a shrewd one, as the original did the book a disservice by concentrating on the Powys connection. Judith Stinton's book deserves a wider readership; she writes with a genuine enthusiasm that will provoke the interest of readers in other twentieth century writers associated with Chaldon Herring, including Sylvia Townsend Warner, Valentine Ackland, David Garnett, Gamel Woolsey and Alyse Gregory. The other great presence in the 
book is of course Chaldon Herring itself, and the beautiful landscape of which it is a part. Stinton's fascination with this area of Dorset is just as infectious as her enthusiasm for the creative circle who made it their home. Highly recommended!

Ray Russell

\section{Copyrighted image removed}

Sylvia and fellow Communists outside 24 West Chaldon, from Chaldon Herring. 